\title{
ОСОБЛИВОСТІ СТАНУ ЗДОРОВ'Я, РУХОВОЇ АКТИВНОСТІ ТА ХАРЧУВАННЯ ШКОЛЯРІВ-СПОРТСМЕНІВ (ОГЛЯД ЛІТЕРАТУРИ)
}

Львівський національний медичний університет імені Данила Галицького

Резюме. На основі порівняльного аналізу даних літератури про стан здоров'я і фізичний розвиток школярів, які займалися і не займалися спортом, встановлено, що у школярів-спортсменів переважали хвороби кістково-м'язової системи, очей, органів дихання, скарги на болі й ушкодження різних відділів опорнорухового апарату; вищою виявилася частота дисгармонійного розвитку за рахунок як недостатньої, так і надлишкової маси тіла. Стан здоров'я юних спортсменів залежав від їх віку, стажу занять спортом, спортивної

Вступ. Стан здоров'я дітей, зокрема шкільного віку, залишається актуальною медикосоціальною проблемою і характеризується прогресуючим погіршенням, скороченням кількості здорових осіб, збільшенням числа гострих і хронічних захворювань усіх класів, морфофункціональних відхилень, розладів психіки та поведінки, зниженням функціональних можливостей та адаптації до розумових і фізичних навантажень $[6,8,9,11,14,15,17,24-26]$. До основних причин цього належать соціально-економічні та медикосоціальні фактори, передусім зниження рівня життя, медичної культури, ефективності профілактичних заходів, недостатні можливості донозологічної діагностики [15], екологічні, психологопедагогічні фактори, перш за все впровадження у навчальний процес педагогічних інновацій без урахування індивідуальних і вікових особливостей дітей [12], постійне зростання інформаційних навантажень, несприятливі умови шкільного середовища, нераціональні режими життєдіяльності дітей, особливо недостатня рухова активність (шкільна гіподинамія) і недоліки харчування [8, 9, 25, 26, 32].

Рухова активність - важливий елемент способу життя і поведінки дітей, вагомий засіб збереження, зміцнення їх здоров'я і профілактики впливу негативних чинників - залежить від соціально-економічних умов суспільства, рівня його культури, організації фізичного виховання у школі, позашкільних масових і самостійних занять фізкультурою і спортом, доступності спортивних споруд і місць відпочинку, особливостей вищої нервової діяльності та функціональних резервів організму, статі, віку, стану здоров'я дітей, соціальної підтримки батьків, вчителів, однолітків, мотивації дитини [7, 12, 29]. Як недостатня рухова активність, властива школярам унаслідок нераціональної організації навчання і відпочинку, навчальних перевантажень, ігнорування фізичного виховання, так і надмірний іiі рівень, поєднаний із фізичними навантаженнями і спрямований на досягнення високих спортивних результатів, підвищують ризик виникнення відхилень морфо- орієнтації, рівнів тренувальних навантажень, фактичного харчування. Наголошена необхідність вивчення й оцінки стану здоров'я і фізичного розвитку школярівспортсменів з урахуванням їх рухової активності, енерговитрат, фактичного харчування і розроблення на цій основі диференційованих за віком і статтю норм харчування юних спортсменів різної спортивної орієнтації.

Ключові слова: школярі-спортсмени, здоров'я, фізичний розвиток, харчування.

функціонального розвитку і стану здоров'я дітей $[7,8,20]$.

Важливою умовою нормального росту і розвитку дітей, збереження їх здоров'я і профілактики захворювань виступає раціональне харчування, яке повинно повністю задовольняти потреби організму в енергії, пластичних і біологічно активних нутрієнтах. Дитина внаслідок іiі функціональної незрілості реагує на незбалансованість харчування порушеннями фізичного і психічного розвитку, гомеостазу, послабленням природного і набутого імунітету [30].

До провідних шляхів збереження і зміцнення здоров’я школярів, підвищення рівня їх фізичного розвитку i профілактики гіподинамії належить поряд з раціональною організацією фізкультурнооздоровчої роботи у школі широке залучення дітей до занять спортом у дитячо-юнацьких спортивних школах (ДЮСШ) і спортивних секціях [24]. Найбільш популярні в дітей і підлітків ігрові (футбол, баскетбол, волейбол) і складнокоординаційні види спорту (гімнастика, спортивні танці), якими займаються понад третини школярів, рідше - швидкісно-силові (легка атлетика), циклічні види (лижний і велоспорт) і спортивні двобої [24]. Однак сучасний дитячо-юнацький спорт характеризується зниженням вікового цензу на всіх етапах підготовки юних спортсменів, інтенсифікацією навчально-тренувального процесу, що призводить до збільшення сумарного навантаження на дитячий організм, який зазнає одночасного впливу багатьох чинників ризику: факторів спортивної діяльності, зокрема підвищених фізичних і психоемоційних навантажень, пов'язаних із заняттями спортом, умов і режимів організації тренувань у сукупності $з$ несприятливими чинниками загальноосвітньої школи і нераціональним харчуванням. Ці фактори можуть спричинити виникнення і розвиток у юних спортсменів різних метаболічних, морфофункціональних порушень, донозоологічних станів і захворювань [8, 24, 30].

Мета дослідження. На основі аналізу наукової літератури останніх років провести порівняльну оцінку стану здоров'я, рухової активності та

( ) С.Л. Няньковський, О.Б. Пластунова, 2016 
харчування школярів, які займаються і не займаються спортом, і виявити особливості цих показників у юних спортсменів.

Матеріал і методи. Найбільш значимими критеріями індивідуального та колективного здоров'я дітей вважають відповідний вікові рівень фізичного, нервово-психічного й інтелектуального розвитку; достатню соціальну і функціональну адаптацію; високий ступінь резистентності до несприятливих впливів; відсутність донозоологічних станів і хронічних захворювань [25]. Стан здоров'я дітей вивчають за частотою скарг [15], показниками первинної (уперше виявленої) захворюваності, поширеності хвороб, патологічної ураженості [9], рівнями фізичного здоров'я, що характеризують функціональні резерви організму [26]. Одним із провідних критеріїв стану здоров'я, чутливим індикатором впливу довкілля, віддзеркаленням способу життя і соціального благополуччя дитячої популяції $\epsilon$ рівень фізичного розвитку, який характеризує особливості формування організму дитини і ступінь іiі морфофункціональної зрілості на кожному етапі онтогенезу [24]. Основу оцінки фізичного розвитку становлять показники зросту (ЗР), маси тіла (МТ), окружності грудної клітки (ОГК), життєвої ємкості легень (ЖЕЛ), м'язової сили кисті (МСК), які порівнюють зі стандартами, складеними за методами сигмальних відхилень (Z-шкал), шкал регресії, перцентилів, головних компонент, а також iз нормами індексів Ерісмана, Кетле, Піньє, Пушкарьова, індексу маси тіла як об'єктивного маркеру здоров'я й адекватності харчування, життевого і силового індексів тощо $[1,18,22]$. Експертами BOO3 методом Z-шкал за індексом маси тіла розроблені стандарти фізичного розвитку дітей віком 5-19 років, однак вони не враховують генетичних, біологічних, етнічних особливостей, соціально-економічних, психосоціальних, екологічних умов росту і розвитку, особливостей рухової активності та харчування дітей різних регіонів планети [35], а надійність цих стандартів у порівнянні з вітчизняними, складеними за шкалами регресії, не перевищує 50 \% [22]. Оцінку рухової активності здійснюють за кількістю локомоцій протягом доби [21], хронометражним методом [7] з подальшим розрахунком індексу рухової активності [14], добових енерговитрат за рекомендаціями ФАО/ВООЗ [20] або на основі метаболічних еквівалентів [7], оцінку харчування - анкетно-опитувальним та анкетно-ваговим методами, а в організованих колективах - за менюрозкладками [30].

Результати дослідження та їх обговорення. У першому десятилітті нинішнього століття в Україні кількість дітей, які вели активний спосіб життя і регулярно займалися спортом, зменшилася на $20 \%$; дітей, які займалися тільки фізкультурою за шкільною програмою - на $6 \%$. Водночас число дітей, які взагалі не відвідували уроків фізкультури і спортивних секцій, зросло на 9,5\%. Лише 6,5 \% дітей тривалий час (більше одного року) займалися спортом [32]. За іншими оцінками регулярно займалися спортом $25 \%$ міських і $11 \%$ сільських школярів, із різних причин не відвідували уроків фізкультури близько 5 \% учнів, перебували на свіжому повітрі дві години і більше $57 \%$ міських і 75 \% сільських школярів, майже $60 \%$ з них стільки ж часу проводили за комп'ютером, телевізором або мобільним телефоном [15]. У школярів набуває поширення малорухомий спосіб життя, лише кожний п'ятий учень має достатній рівень рухової активності, а 60 \% українських школярів неспроможні виконати вимоги загальноєвропейських тестів 3 фізичної підготовки [16].

Фізичні навантаження i рухова активність дітей молодшого шкільного віку на уроках фізкультури недостатні, не відповідають оптимальній моторній щільності уроку, що спричиняє збільшення частоти скарг на загальну слабкість, біль голови, неспокійний сон, підвищену пітливість, емоційну лабільність [16]. Рівні рухової активності й енерговитрати 7-річних школярів різної статі виявилися практично однаковими, школярів іншого віку - недостовірно вищими у хлопців, ніж у дівчат; школярів усіх віково-статевих груп - вищими у будні дні порівняно з вихідними на 10-12 \% і зменшувалися від молодшого (7-10 років) до середнього (11-14 років) і старшого віку (15-17 років), особливо у вікових діапазонах 9-10 i 14-15 років. Однак розроблені автором шкали оцінки рухової активності за добовими енерговитратами свідчать про незначні коливання цих показників у різні вікові періоди дитинства [7]. За іншими оцінками рухова активність хлопців відзначалася хвилеподібним характером 3 підйомами у 7-11 і 15 років і спадами у 12-14 і 17 років, дівчат - незначними віковими коливаннями i не залежала від рівня фізичної підготовленості [14]. У 14-15-річних юнаків - мешканців великого міста рівень рухової активності був вищим на 6-12 \%, ніж у дівчат цього віку; у підлітків невеликого міста різнився неістотно, але в обох випадках виявився низьким і становив лише 35 \% гігієнічної норми [29]. Сільські підлітки віком 13 років характеризувалися вищою руховою активністю, меншим часом відпочинку і нижчою частотою ожиріння, ніж їх міські однолітки [37]. У фізично неактивних школярів віком 10-15 років, які займалися спортом менше 30 хв/день, багато часу проводили біля телевізора, нерегулярно снідали і не контролювалися батьками у виборі раціону харчування, спостерігалася вища поширеність ожиріння [40]. Рухова активність 14-16річних підлітків різко зменшувалася під час літніх i, особливо, зимових канікул [18]. Встановлено прямий сильний кореляційний зв'язок рухової активності (кількості локомоцій) 3 величиною основного обміну, МТ, ОГК, помірний іiі зв'язок із ЖЕЛ, ЗР, харчовими звичками і рівнем гігієнічної грамотності, зокрема швидкістю споживання їі, дотриманням правил особистої гігієни, i обернений помірний зв'язок із МСК [20]. Однак 
оцінка рівнів рухової активності та енерговитрат школярів-спортсменів у літературі відсутня.

У першому десятилітті нинішнього століття спостерігалася негативна динаміка споживання дітьми окремих харчових продуктів: кількість дітей, у раціонах яких відсутні молоко і молочні продукти, збільшилася на 17 \%, фрукти і овочі на $23 \%$, сільських дітей, які споживали м'ясні продукти один раз на тиждень, - удвічі [32]. За результатами опитування батьків нерегулярно харчувалися близько 10 \% міських і 20 \% сільських школярів, раціони 15 і 30 \% із них були недостатніми за вмістом поживних речовин, їли 1-3 рази/день замість належних 4-5 разів 35 і $65 \%$, обідами у школі забезпечувалися 32 і 49 \% дітей, майже третина учнів не снідала перед школою, пізно вечеряли 40 і 46 \% дітей відповідно. Менше 50 \% школярів споживали м'ясні продукти щоденно, $20 \%$ - лише раз на тиждень, $45 \%$ дітей їли мало риби, $16 \%$ - м'яса, 10-13\% - овочів і фруктів. Близько половини сільських дітей взагалі не вживали молока [15]. Енергетична цінність раціонів 30-40 \% школярів виявилася недостатньою i була пов'язана 3 дефіцитом білка за достатнього споживання жирів (95-105 \%) і надмірного споживання вуглеводів (понад 20 \% від норми) [32].

За фрагментарними нечисленними оцінками харчуванню юних спортсменів також властиві енергетична неадекватність і незбалансованість за основними макро- і мікронутрієнтами. У раціонах 13-17-річних гребців спостерігався дефіцит енергоцінності, вмісту жирів, більшості вітамінів і мінеральних речовин, велосипедистів - менш істотний дефіцит енергіi, борців - надлишок енергії, білків і жирів за нестачі вуглеводів і вітамінів $\mathrm{A}, \mathrm{B}_{1}, \mathrm{~B}_{2}$ у раціонах борців і велосипедистів [30]. Раціони плавців 11-16 років містили недостатню кількість фруктів, овочів, зернових, молочних продуктів і надлишок жирів, зокрема насичених, вищий за норми на 36 і 12 \% відповідно, дефіцит вітаміну D і кальцію, що на тлі оптимального атлетичного навантаження підвищувало ризик виникнення хронічних захворювань, передусім остеопорозу [36]. Відомо, що вимоги до харчування спортсменів визначаються видом спорту, віком, статтю, етапом тренувального процесу і порою року [30], однак науково обгрунтовані на основі енерговитрат організму норми харчування юних спортсменів різних спортивних профілів донині відсутні.

За оцінками МО3 України в структурі первинної захворюваності та поширеності хвороб у дітей віком 7-14 років домінують хвороби органів дихання, травлення, очей та їх придаткового апарату, ендокринної та кістково-м'язової системи, шкіри та підшкірної клітковини [15]. Разом 3 тим виявлено певні вікові особливості показників здоров'я дітей. Порушення стану здоров'я мали $70 \%$, хронічні захворювання - $30 \%$ дітей, які готувалися до школи [25]. У першокласників найбільша питома вага належала хворобам носоглотки (хронічні аденоїдити, тонзиліти, гіпертро- фія аденоїдів і мигдаликів), опорно-рухового апарату (порушення постави, форми грудної клітки, склепіння стопи, сколіози, плоскостопість), органів травлення (дискінезії жовчовивідних шляхів, функціональні розлади шлунка, кишечнику, панкреатопатії, хронічні холецистити, гастрити), порушенням функції зору, нервової, ендокринної, серцево-судинної системи [17]. У 70 \% першокласників спостерігалися низька фізична і розумова працездатність і фізична підготовка, які не відповідали шкільному навантаженню [25], їх адаптаційні можливості залежали від рівня фізичного розвитку, обсягу рухової активності, фізичної працездатності та підготовки [12]. Часто першокласники скаржилися на періодичні болі в животі, нудоту, швидку втомлюваність, пригнічення настрою, біль голови, порушення сну, апетиту, що трактується як прояви синдрому шкільної дезадаптації $[15,25]$.

За іншими оцінками, у дітей молодшого i середнього шкільного віку передували ураження кістково-м'язової системи (порушення постави і сколіоз, частота яких зростала з роками навчання, плоскостопість, карієс), шлунково-кишкового тракту (запори, дисфункції біліарного тракту, гастродуоденіти, холецистити), вегетовісцеральні дисфункції, які вважають факторами ризику формування соматичної патології, часто супроводжуються захворюваннями шлунка, кишечнику, синдромом шкільної дезадаптації і водночас впливають на фізичний і психічний розвиток дітей. Iз вегетосудинною дисфункцією пов'язують зміни серцево-судинної системи (біль у ділянці серця, систолічний шум, розщеплення або послаблення I тону), із нейроциркуляторною дисфункцією болі голови і деякі хвороби нервової системи, які посідали третє місце в структурі захворюваності. Значною була поширеність хвороб носоглотки (хронічного тонзиліту, часто поєднаного з аденоїдитом, гіпертрофії мигдаликів), ожиріння, переважно I ступеня, патології зору (частіше міопії, рідше гіперметропії, астигматизму, косоокості), алергічних захворювань (атопічного дерматиту i бронхіальної астми без клінічних проявів). У молодшому і середньому шкільному віці кількість здорових дітей (І група здоров'я) коливалася за різними оцінками від 5 до $23 \%$, дітей із хронічними захворюваннями (III група) - від 47 до $65 \%$, значною була поширеність морфофункціональних відхилень (II група). Старший шкільний вік, у якому завершується статеве дозрівання i підвищується чутливість до впливу різних чинників, характеризувався зменшенням майже удвічі числа здорових дітей (із $36 \%$ у I до $20 \%$ в XI класі) і збільшенням частоти хронічної патології ( 322,5 до 40,5 \%). Основну групу фізвиховання відвідували лише $20 \%$, підготовчу - 32 \%, спеціальну - $48 \%$ учнів [26]. В окремих регіонах у дітей 12-14-річного віку на друге-третє місця після хвороб органів дихання виходили хвороби нервової та кістково-м'язової системи, а хвороби травної й ендокринної системи реєструвалися 
рідше; нижче середнього і низький рівні здоров'я мали понад 60 \% дітей. У 12-річних дівчат і 13річних хлопців спостерігалися найнижчі рівні соматичного здоров'я, які у хлопців обернено помірно корелювали з МТ [9]. Упродовж п'яти років навчання частота порушень зору і нервовопсихічних розладів зростала в 1,5 раза, опорнорухового апарату - у 2-3 рази, патології органів травлення - у 3-4 рази [25].

Встановлено позитивний вплив на рівень здоров'я дітей належних матеріально-побутових умов і психологічного клімату сім'ї, соціального та культурного рівня батьків, рівня освіти матері, збалансованості харчування, організації дозвілля, передусім тривалості перебування на свіжому повітрі, і негативний вплив шкідливих звичок батьків $[9,12]$, а також обернений помірний кореляційний зв'язок рівнів здоров'я з поширеністю хвороб [9]. Розроблені різноманітні підходи до визначення причинно-наслідкових зв'язків у системі “здоров'я - чинники життєдіяльності”, що дозволяють визначити роль етіологічних факторів і факторів ризику у формуванні здоров'я дітей і на цій основі обгрунтувати адекватні профілактичні заходи [6]. Запропоновані шкали для оцінки здоров'я й адаптації школярів, а також методи покращання їх здоров'я традиційними й інноваційними засобами фізвиховання [12].

Захворюваність дітей, які займалися спортом, відзначалася певними особливостями. У структурі патологічної ураженості вихованців ДЮСШ віком 5-10 років провідні місця посідали хвороби кістково-м'язової системи, передусім порушення постави і плоскостопість, ока та його придаткового апарату (міопія й астигматизм), органів дихання, рідше - хвороби серцевосудинної (кардіоміопатії), ендокринної (ожиріння) і травної систем. У юних спортсменів - представників спортивних двобоїв, особливо дівчат, вищою виявилася поширеність порушень постави й ожиріння, циклічних та ігрових видів спорту хвороб дихальної системи, циклічних видів Хвороб системи кровообігу [8]. У кожного п'ятого вихованця ДЮСШ олімпійського резерву віком 13-17 років спостерігалися функціональні порушення i хронічні захворювання, третина яких - системи дихання [30]. Юні волейболісти часто скаржилися на біль у спині, колінних суглобах, травми плеча, розтягнення зв'язок гомілковостопних суглобів, деформації пальців і анемiї [38].

Гармонійний, відповідний вікові фізичний розвиток властивий здоровій дитині, його диспропорції зумовлені гіподинамією, надмірною масою тіла, різними захворюваннями [27]. Сучасні українські школярі віком 12 років достовірно більші за ЗР, хлопці 6-7, 9, 11-13, 15 і дівчата 7-9, 11-14 років - за МТ, хлопці 11-12 і дівчата 11-14, 16 років - за ОГК, ніж їх однолітки кінця минулого століття; школярі інших віково-статевих груп не відрізняються або менші від останніх за цими показниками, що суперечить висновкам автора про астенізацію [19] і граціалізацію (збільшення 3Р і зниження МТ) дітей, особливо дівчат [21]. За іншими оцінками, протягом першого десятиріччя нинішнього століття кількість школярів із середнім розвитком зменшилася на $11 \%$, із надлишковою МТ й ожирінням зросла на $18 \%$ [32].

Вище і нижче середнього рівень фізичного розвитку спостерігався відповідно в 11-13 \% i 13 \% школярів, дисгармонійний - у 13-14 \% дітей, різко дисгармонійний - у 2,5 \% хлопців, переважно внаслідок надлишкової МТ, і 5 \% дівчат, передусім через значний ii дефіцит, а також за рахунок нижчого за належний ОГК у хлопців і дівчат. У 6-річному віці гармонійний розвиток мали $92 \%$ хлопчиків і $78 \%$ дівчаток, різко дисгармонійний - 4 і $12 \%$ дітей відповідної статі; у 10 і 15 років число дисгармонійно розвинених хлопців зростало у 3 і 5 разів, дівчат невірогідно збільшувалося в 1,5 і 1,6 раза; у 13 років унаслідок пубертатного “стрибка” ЗР дисгармонійно розвинених хлопців налічувалося утричі більше, ніж дівчат [19]. За іншими оцінками, у молодшому та середньому шкільному віці вище середнього і високий фізичний розвиток мали $19 \%$, нижче середнього - 2,5\%, дисгармонійний розвиток, переважно за рахунок надлишкової МТ, - $13 \%$ учнів [26]. У першокласниць, які розпочали навчання у 6 років, частота пікноїдної тілобудови за Пушкарьовим виявилася більшою, нормостеноїдної й астеноїдної - меншою, ніж у 7-річних; у 6-річних хлопчиків частота пікноїдної тілобудови, навпаки, була дещо меншою, астеноїдної більшою, ніж у 7-річних, за однакової частоти нормостеноїдної тілобудови. Юнакам старшого шкільного віку властивий дисгармонійний розвиток за пікноїдним типом $з$ підвищеною МТ, дівчатам - астеноїдний його тип [17]. Із віком кількість школярів із надлишковою МТ зменшувалася, із іiі дефіцитом - збільшувалася, однак поширеність надмірної МТ переважала над іiі дефіцитом; близько 55 \% школярів мали низький і нижче середнього ЗР, особливо у віці 8-10 і 13 років; дисгармонійно розвинених дівчат було удвічі більше, ніж хлопців; діти 3 дефіцитом або надлишком МТ і низьким ЗР складали групу ризику, чисельність якої сягала 40 \% 3 максимумом у 1516-річних хлопців і 13-14-річних дівчат; фізичний розвиток дітей поступався стандартам, за винятком хлопчиків і дівчаток віком 7-8 і 11-12 років і хлопців 15 років; найбільше відхилень розвитку реєструвалося в 16 років [27].

У літературі наводяться розбіжні терміни максимальних річних приростів 3Р і МТ школярів: одні автори спостерігали “стрибки” ЗР у хлопців віком 10-11 і 13-14 і дівчат віком 10-12 років за істотних приростів МТ у них відповідно у 1314 і 11-12 років [27]; інші - “стрибки” ЗР у хлопців віком 11 і 15 років за найбільших приростів МТ у них у 9-10 та 15 років і збіжні у часі (10-11 років) максимальні прирости ЗР і МТ у дівчат [32]. Поодинокі автори вказують на нижчі за ві- 
ково-статеві норми фізіометричні показники, поступове зменшення відсотка жирової тканини і зростання ЖЄЛ, силового індексу, рівня фізичної підготовки протягом навчального року, які після літніх канікул погіршувалися за антропометричних параметрів, що відповідали стандартам, у 1416-річних підлітків [18]. Встановлено прямий сильний кореляційний зв'язок ЗР, МТ і помірний зв'язок ОГК, ЖЕЛ, МСК дітей із величиною основного обміну [6].

Рівень фізичного розвитку і тілобудова як важливі критерії початкового відбору дітей для занять спортом і складання тренувальних програм [10] пов'язані зі специфікою виду спорту, змінюються під впливом фізичних навантажень і мають особливе прогностичне значення, оскільки дозволяють розробляти та впроваджувати профілактичні заходи зі збереження і зміцнення здоров'я юних спортсменів [24]. Майже третина вихованців ДЮСШ віком 5-10 років, найчастіше 3 ігрових видів спорту, відзначалися фізичним розвитком вище середнього і високим; близько 10\%, передусім представники складно-координаційних видів, - розвитком нижче середнього і низьким; майже половина, зазвичай представники складнокоординаційних видів, особливо дівчата, - дисгармонійним розвитком із дефіцитом МТ, частота якого збільшувалася на другий рік занять; понад 20 \%, передусім представники двобоїв, - надмірною МТ; гармонійний розвиток частіше реєструвався у дітей, які займалися циклічними та ігровими видами спорту [24]. Надлишкова МТ за рахунок гіпертрофії м'язів реєструвалася у $23 \%$ борців і 11 \% гребців, іiі дефіцит - у 15-16\% юних спортсменів цих профілів і 8 \% велосипедистів; надмірний харчовий статус за індексом МТ - у $19 \%$ борців, 10 \% гребців і 1 \% велосипедистів, недостатній - у 10 \% спортсменів; дисгармонійний і різко дисгармонійний розвиток, зумовлений невідповідністю ОГК і ЗР внаслідок особливостей м'язової діяльності та спортивного стажу, - у 73 \% гребців, $63 \%$ борців і лише $14 \%$ велосипедистів - 13-17-річних вихованців ДЮСШ [30].

Показники фізичного розвитку дітей 8-10річного віку, які займалися у спортивних секціях не менше 4 год/тиждень і фізкультурою за шкільною програмою 3 год/тиждень, виявилися вищими, ніж у школярів, які лише відвідували уроки фізвиховання [11]. У 7-10-річних школярів, які займалися плаванням, індекс Кетле залишався незмінним, окружності різних частин тіла і товщина шкірно-жирової складки збільшувалися інтенсивніше, ніж в однолітків, які плаванням не займалися [4]. Молодші школярі - хокеїсти із ЗР, МТ на рівні середніх величин і вище середнього ОГК не відрізнялися від однолітків - учнів звичайних шкіл, але перевищували останніх за рівнем фізичної підготовки, що, на думку авторів, свідчить про відсутність впливу додаткових навантажень на антропометричні показники, позитивний вплив навантажень на фізичний статус дітей і узгоджується з результатами інших дослідників [31]. Заняття різними видами спорту менше 5 год/тиждень суттєво не позначалися на основних антропометричних показниках дітей віком 9-11 років, але найкращий профіль фізичного розвитку мали дівчата-гімнастки [39]. За рівнями фізичного розвитку 7-9-річні школярі, які займалися спортивною акробатикою, істотно не відрізнялися від однолітків, які лише відвідували уроки фізкультури, що пояснюється спрямованістю початкової спортивної орієнтації та шкільних уроків фізкультури на загальну фізичну підготовку [13].

Антропометричні показники, ЖЄЛ самбістів, дзюдоїстів і велогонщиків середнього шкільного віку зазвичай перевищували відповідні параметри їх однолітків, які не займалися спортом [1]. Лижники 10-12 років за ЗР і МТ суттєво не відрізнялися, але за ОГК, індексом Кетле та індексом фізичного розвитку перевищували ровесників, які лише відвідували уроки фізкультури [5]. У 10-15-річних футболістів і баскетболістів 3 мезоморфним соматотипом, який домінував у футболістів, ЖЄЛ була вищою, ніж в осіб доліхоморфного соматотипу, що переважав у баскетболістів [3]. Показники МТ, ЖЕЛ, МСК в юнаків і дівчат віком 14-16 років, які займалися туризмом, виявилися достовірно більшими, ніж у підлітків, які ним не займалися [28]. У 14-16-річних волейболістів спостерігалися вищі абсолютні показники МСК, ніж у хлопців, які спортом не займалися [2], а волейболістки віком 13-14 років відзначалися нижче середнього або низьким ЗР, середньою МТ і МСК за оціночними таблицями, складеними за сигмальними відхиленнями [10]. Альпіністи 10-16 років характеризувалися нижчими показниками 3Р, МТ, шкірно-жирової складки і вищою MCK порівняно з юнаками, які займалися іншими видами спорту, за несуттєвої різниці індексу MT в обох групах [34]. Із збільшенням спортивного стажу юних футболістів різниця показників їх фізичного розвитку та відповідних показників учнів звичайних шкіл зростала, однак вірогідно більшими футболісти виявилися за ЗР лише в 17 років, за МТ і ОГК у 15-17 років, що не узгоджується $з$ висновками деяких авторів, які спостерігали тотожні показники ЗР у спортсменів і неспортсменів віком 11 і 17 років, нижчі його показники в юних спортсменів інших вікових груп і пов'язували це явище 3 відбором низькорослих юнаків для занять певними видами спорту або надмірними навантаженнями футболістів, що може перешкоджати нормальному росту кісток [23]. Спортивна орієнтація, вік юних спортсменів, рівень тренувальних навантажень та емоційного напруження під час змагань визначали ступінь кореляційних зв'язків антропометричних показників між собою й іншими показниками функціонального стану [1].

Надмірні тренувальні навантаження призводили до значного скорочення приросту МТ борців-самбістів віком 12-14 років; у борців- 
дзюдоїстів віком 10-12 і 12-14 років, навпаки, МТ збільшувалася інтенсивніше, ніж у представників інших спортивних профілів, а соматичний розвиток велогонщиків мав більш рівномірний характер зі “стрибками” ЗР у 10-12 і 12-14 років на тлі істотного зростання ЖЕЛ у юних спортсменів цих профілів [1]. Найбільші прирости ЗР у юних футболістів та їх однолітків зі звичайних шкіл зафіксовані в $13-15$ років (13 і $10 \%$ відповідно), МТ та індексу Кетле - у 15-річних футболістів і 14-річних школярів (31 і $19 \%$ за масою; 23 і $12 \%$ за індексом), ОГК - у 15 років в обох групах (13 i $5 \%$, рівень розвитку футболістів за індексом Кетле підвищувався від нижчого за середній в 11-13 років до середнього в 14-16 років і вище середнього - у 17 років [23]. У 13-14-річних вихованців секції з футболу протягом навчального року істотно покращувалися показники ЖЕЛ і силового індексу за недостовірних змін цих показників у контрольній групі [33].

Таким чином, порівняльний аналіз стану здоров'я школярів, які не займалися і займалися спортом, свідчить про певні його особливості в юних спортсменів. Зокрема, на тлі домінування за офіційними даними хвороб органів дихання i травлення в українській дитячій популяції віком 7-14 років [15] і неоднозначних оцінок захворюваності школярів різного віку науковцями, які вказують на переважання хвороб носоглотки й опорно-рухового апарату в молодшому шкільному віці [17] або уражень кістково-м'язової системи і шлунково-кишкового тракту у школярів молодшого та середнього віку [26], у структурі захворюваності молодших школярів-спортсменів за нечисленними даними літератури провідні місця посідали хвороби кістково-м'язової системи, очей і органів дихання [8], у юних спортсменів середнього та старшого шкільного віку - органів дихання [30]. Очевидно, що порушення постави i плоскостопість, тим більше міопія й астигматизм, які передували у школярів-спортсменів молодшого віку, скоріше зумовлені негативним впливом загальноосвітніх чинників, але вища поширеність порушень постави й ожиріння у представників спортивних двобоїв, хвороб дихальної системи у представників циклічних та ігрових видів спорту, хвороб системи кровообігу у представників циклічних видів порівняно 3 представниками інших спортивних профілів [8], а також специфічні скарги й ушкодження юних волейболістів [38] не виключають негативного впливу спортивних навантажень і середовища спортивних об'єктів на стан здоров'я юних спортсменів.

На тлі наявних у літературі неоднозначних оцінок фізичного розвитку дитячої популяції України, пов'язаних, на наш погляд, передусім із застосуванням місцевих, зазвичай застарілих стандартів або різних масо-зростових індексів, іноді - так званих вікових норм, які встановлені на основі сигмальних відхилень від середньої арифметичної і не враховують зв'язків між окремими антропометричними показниками, а також розбі- жних термінів максимальних річних приростів 3Р і МТ дітей, недостатнього висвітлення оцінок фізичного розвитку за його фізіометричними показниками, не менш суперечливими видаються нечисленні оцінки фізичного розвитку школярівспортсменів як важливого критерію їх початкового відбору для занять спортом і складання тренувальних програм. Якщо в популяції фізичний розвиток вище і нижче середнього за сигмальними відхиленнями реєструвався у співвідношенні 1:1 [19], у дітей молодшого та середнього шкільного віку - у співвідношенні 8:1 [26], а частота дисгармонійного розвитку коливалася у межах 13-23 \% за рахунок як надлишку, так і дефіциту MT у дітей різних віково-статевих груп $[19,26,27]$, то у вихованців ДЮСШ віком 5-10 років співвідношення вищих і нижчих за середні ступенів фізичного розвитку становило $3: 1$, частота дисгармонійного розвитку сягала майже 70 \%, дефіцит МТ переважав над іiї надлишком у 2,5 раза. Представники ігрових видів спорту відзначалися розвитком вищих ступенів, складнокоординаційних видів - розвитком нижчих ступенів і дефіцитом МТ, двобоїв - надлишком МТ [24]. У спортсменів віком 13-17 років частота дисгармонійного розвитку не перевищувала 38-39 \%, надлишкова МТ за рахунок розвитку м'язів переважала у борців, ії дефіцит - у представників циклічних видів - гребців і велосипедистів [30]. За одними оцінками заняття спортом сприяли збільшенню показників фізичного розвитку дітей молодшого шкільного віку [11], за іншими оцінками не позначалися на основних антропометричних показниках унаслідок спрямування початкової спортивної орієнтації на загальну фізичну підготовку [13,39], але призводили, зокрема заняття плаванням і хокеєм, до інтенсивного зростання різних окружностей, товщини шкірно-жирової складки, рівнів фізичної підготовки порівняно 3 молодшими школярами, які спортом не займалися $[4,31]$. У борців-самбістів і дзюдоїстів, велогонщиків середнього шкільного віку спостерігалися вищі, ніж в однолітків-неспортсменів, антропометричні показники і ЖЕЛ [1], у лижників - вищі ОГК, індекси Кетле та фізичного розвитку [5], у баскетболістів і футболістів - вища ЖЕЛ [3], у футболістів - вищі ЖЕЛ і силовий індекс [33], натомість альпіністи відзначалися нижчими показниками 3Р, МТ і вищою МСК [34]. У футболістів старшого шкільного віку виявлено вищі, ніж в учнів звичайних шкіл, антропометричні показники [23], у волейболістів і туристів - вищі МТ, ЖЕЛ, МСК $[2,28]$, що, імовірно, пов'язано 3 впливом на фізичний розвиток юних спортсменів цих вікових груп більшого спортивного стажу i тренувальних навантажень. Наведені в літературі оцінки фізичного розвитку юних спортсменів, зокрема переважання мезоморфного соматотипу у футболістів і доліхоморфного соматотипу в баскетболістів [3], нижчі 3Р і МТ альпіністів [34], не виключають впливу початкового відбору дітей різних соматотипів для занять певними видами 
спорту. Джерела літератури містять досить розбіжні терміни “стрибків" ЗР і МТ юних спортсменів різних профілів, іноді відмінні від цих термінів в учнів звичайних шкіл.

Таким чином, вплив на стан здоров'я і фізичний розвиток школярів-спортсменів різних віково-статевих груп особливостей спортивної діяльності з урахуванням притаманних кожному виду спорту рівнів рухової активності, зумовлених ними енерговитрат організму і відповідності фактичного харчування дітей цим енерговитратам досі залишається невивченим. На тлі негативних тенденцій фактичного харчування школярів України харчуванню юних спортсменів за нечисленними оцінками також властиві енергетична неадекватність і незбалансованість за основними макро- i мікронутрієнтами [15, 32]. Надлишок енергії, білків і жирів у раціонах можна вважати одною з причин надлишкової МТ борців, дефіцит енергії й окремих нутрієнтів - недостатньої МТ велосипедистів i, особливо, гребців [30]. Однак науково обгрунтовані норми харчування юних спортсменів, які би повністю задовольняли їх фізіологічні потреби в енергії й основних нутрієнтах з урахуванням спортивної орієнтації, віку, статі, етапу тренувального процесу і сприяли збереженню та зміцненню здоров'я дітей, донині відсутні.

\section{Висновок}

Стан здоров'я школярів, які активно займаються спортом, у порівнянні з цими показниками сучасної популяції школярів України характеризується переважанням хвороб кістково-м'язової системи, очей, органів дихання і скарг на болі й ушкодження різних відділів опорно-рухового апарату, вищою поширеністю дисгармонійного фізичного розвитку за рахунок як недостатньої, так і надлишкової, пов'язаної з розвитком м'язів, маси тіла, і залежить від віку, стажу занять спортом, спортивної орієнтації, рівнів тренувальних навантажень, стану фактичного харчування.

Перспективи подальших досліджень полягають у необхідності вивчення й оцінки стану здоров'я i фізичного розвитку школярівспортсменів з урахуванням їх рухової активності, енерговитрат, фактичного харчування і розроблення на цій основі диференційованих за віком i статтю норм харчування юних спортсменів різної спортивної орієнтації.

\section{Література}

1. Абрамович В.П. Влияние занятий спортом на характер соматического развития и адаптивные возможности кардио-респираторной системы школьников 10-16 лет: автореф. дис. на соискание уч. степени канд. биол. наук; спец. 03.03.01 “физиология” / Абрамович М. П. - Майкоп, 2010. - 26 с.

2. Андрійчук Ю. Вплив секційних занять волейболом на руховий розвиток школярів 14-16 років / Ю. Андрійчук, В. Чижик, В. Романюк // Фізичне виховання, спорт і культура здоров'я у сучасному суспільстві : зб. наук. пр. Волинського нац. ун-ту ім. Лесі Українки. Луцьк: ВНУ ім. Лесі Українки, 2012. - № 4 (20). C. $229-236$.
3. Беленко И.С. Влияние занятий спортом на функциональное состояние нервной и дыхательной систем юных футболистов и баскетболистов 10-15 лет разных соматотипов : автореф. дис. на соискание уч. степени канд. биол. наук; спец. 03.03.01 “физиология” / Беленко И.С. - Майкоп, 2010. - 24 с.

4. Даджані Дж. Контроль фізичної підготовленості дітей 7-10 років в умовах фізичного виховання в початковій школі Республіки Кіпр : автореф. дис. на здобуття наук. ступеня канд. наук з фізичного виховання та спорту; спец. 24.00.02 "Фізична культура, фізичне виховання різних груп населення" / Даджані Дж. - К., 2011. $-22 \mathrm{c}$.

5. Замятіна I. Вплив занять із лижної підготовки на фізичний стан підлітків / I. Замятіна // Фізичне виховання, спорт і культура здоров'я у сучасному суспільстві: зб. наук. пр. Волинського нац. ун-ту ім. Лесі Українки. Луцьк : ВНУ ім. Лесі Українки, 2012. - № 3 (19). C. 208-211.

6. Исследование взаимосвязей между особенностями здоровья и уровнем гигиенических знаний детей школьного возраста / А.Г. Платонова, Л.В. Подригало, О.А. Ровная [и др.] // Педагогічні науки: теорія, історія, інноваційні технології: наук. журнал Сумського ДПУ ім. А.С. Макаренка. - 2014. - № 2 (36). C. 161-168.

7. Калиниченко I.О. Гігієнічна оцінка добової рухової активності дітей 7-17 років / І.О. Калиниченко // Гігієна населених місць. - 2011. - № 57. - С. 317-318.

8. Калиниченко І.О. Оцінка стану здоров'я дітей, які займаються різними видами спорту в системі дитячоюнацьких спортивних шкіл (на прикладі Сумської області) / І.О. Калиниченко, О.О. Скиба // Досягнення біол. та мед. - 2014. - № 1. - С. 34-37.

9. Козакевич В.К. Інформативні критерії оцінки стану здоров'я дітей та підлітків / В.К. Козакевич, О.Б. Козакевич // Перинатология и педиатрия им. Е.М. Лукьяновой. - 2014. - № 4. - С. 82-85.

10. Кондак Н.М. Оцінка рівня фізичного розвитку та фізичної підготовленості волейболісток 13-14 років / Н.М. Кондак, І.В. Гаврилко // Вісн. Чернігів. нац. пед. унту. Сер.: Педагогічні науки. Фізичне виховання та спорт. - 2013. - Вип. 112 (4). - С. 136-138.

11. Лещак О. Зміни морфофункціонального статусу молодших школярів під впливом оздоровчо-рекреаційних заходів в умовах літнього табору / О. Лещак // Вісн. Прикарпат. ун-ту. Фізична культура. - ІваноФранківськ, 2010. - Вип. 11. - С. 34-37.

12. Лясота Т.I. Підвищення адаптаційних можливостей дітей 6-7 років до умов навчання в початковій школі засобами фізичного виховання : автореф. дис. на здобуття наук. ступеня канд. наук 3 фізичного виховання та спорту; спец. 24.00.02 "Фізична культура, фізичне виховання різних груп населення"/ Лясота T.I. - К., 2012. -24 c.

13. Марчук В.М. Віково-статеві особливості фізичного розвитку дітей 7-9 років, які займаються акробатикою / В.М. Марчук // Вісн. Кам'янець-Подільського нац. ун-ту ім. Івана Огієнка. Фізичне виховання, спорт і здоров'я людини. - 2008. - Вип. 1. - С. 71-75.

14. Мацейко I.I. Фізична підготовленість та ії зв'язок з руховою активністю школярів 7-17 років / I.I. Мацейко, С.М. Галандзовський // Педагогічні науки: теорія, історія, інноваційні технології: наук. журнал Сумського ДПУ ім. А.С. Макаренка. - 2014. - № 2 (36). - С. 76-84.

15. Медико-соціальні особливості стану здоров'я школярів м. Львова та Львівської області / С.Л. Няньковський, М.С. Яцула, О.М. Сенкевич [та ін.] // Львів. клін. вісник. - 2013. - № 3. - С. 31-35.

16. Мудрік С. Сучасний стан здоров'я дітей молодшого шкільного віку / С. Мудрік // Фізичне виховання, спорт і культура здоров'я у сучасному суспільстві : зб. 
наук. пр. Волинського нац. ун-ту ім. Лесі Українки. Луцьк : ВНУ ім. Лесі Українки, 2012. - № 2 (18). C. $183-187$.

17. Неділько П.В. Здоров'я та розвиток дітей старшого дошкільного і молодшого шкільного віку / П.В. Неділько, С.А. Руденко // Освіта та розвиток обдарованої особистості. - 2013. - № 3 (10). - С. 60-63.

18. Пальчук М.Б. Контроль фізичного розвитку учнів при переході з середньої до старшої школи в умовах навчального процесу 3 фізичного виховання: автореф. дис. на здобуття наук. ступеня канд. наук з фізичного виховання і спорту; спец. 24.00.02 “Фізична культура, фізичне виховання різних груп населення”/ Пальчук М.Б. - К., 2014. - 20 с.

19. Платонова А.Г. Оценка физического развития городских школьников за период с 1996 по 2008 годы / А.Г. Платонова // Гігієна населених місць. - 2011. № 58. - C. 293-298.

20. Платонова А.Г. Обоснование применения двигательной активности детей как критерия эффективности оздоровления и рекреации / А.Г. Платонова, Л.В. Подригало, К.М. Сокол // Педагогіка, психологія та медико-біологічні проблеми фізичного виховання і спорту. - 2013. - № 11. - С. 72-76.

21. Платонова А.Г. Пространственные и структурнофункциональные особенности организма школьников 8-16 лет Москвы и Киева / А.Г. Платонова // Мед. перспективи. - 2012. - Т. 17, № 2. - С. 84-88.

22. Полька Н.С. До питання оцінки фізичного розвитку школярів за стандартами ВОО3 / Н.С. Полька, А.Г. Платонова // Довкілля та здоров'я (Environment \& Htalth). - 2012. - № 1. - C. 48-52.

23. Романюк В. Особливості фізичного розвитку юних футболістів 11-17 років / В. Романюк // Фізичне виховання, спорт і культура здоров'я у сучасному суспільстві: зб. наук. пр. Східноєвропейського нац. ун-ту ім. Лесі Українки. - Луцьк : Східноєвропейський нац. унт ім. Лесі Українки. - 2013. - № 4 (24). - С. 86-91.

24. Скиба О.О. Особливості фізичного розвитку дітей, які займаються різними видами спорту / О.О. Скиба // Вісн. пробл. біол. і мед. - 2013. - Т. 1 (98), № 1. С. $268-271$.

25. Стан здоров'я школярів України / С.Л. Няньковський, М.С. Яцула, М.І. Чикайло, І.В. Пасечнюк // Здоровье ребёнка. - 2012. - № 5 (40). - Режим доступу: http:// www.mif-ua.com/archive/issue-32810/

26. Сучасні особливості стану здоров'я дітей молодшого і середнього віку м. Києва / О.В. Тяжка, Л.М. Казакова, О.А. Строй [та ін.] // Здоровье ребёнка. - 2011. - № 4 (31). - Режим доступу: http://www.mif-ua.com/archive/ issue-17741/

27. Твердохліб М.М. Оцінка стану фізичного розвитку дітей шкільного віку в динаміці навчального процесу / М.М. Твердохліб, С.В. Дяченко // Педагогічні науки: теорія, історія, інноваційні технології: наук. журнал Сумського ДПУ ім. А.С. Макаренка. - 2014. - № 2 (36). - С. 324-330.

28. Товстоп'ятко Ф.Ф. Дослідження впливу туристичнокраєзнавчої діяльності на фізичний розвиток школя- рів / Ф.Ф. Товстоп'ятко, Е.А. Криволапов // Вісн. Запоріз. нац. ун-ту. -2012. - № 2 (8). - С. 106-110.

29. Томенко О.А. Рівень рухової активності підлітків та шляхи його підвищення на основі використання заходів оздоровчо-рекреаційного спрямування / О.А. Томенко // Слобожан. наук.-спорт. вісник. - Харків: ХДАФК, 2013. - - № 3. - С. 19-24.

30. Топанова А.А. Оценка пищевого статуса и индивидуальная коррекция питания юных спортсменов : автореф. дис. на соискание уч. степени канд. мед. наук; спец. 14.00.07 "Гигиена" / Топанова А.А. - СПб., 2009. $-21 \mathrm{c}$.

31. Физическое развитие и физическая подготовленность учащихся младших классов, занимающихся и не занимающихся спортом / О.В. Тозик, О.А. Ковалева, О.С. Даниленко [и др.] // Наука і освіта: наук.-практ. ж. Південного наукового Центру АПН України. 2012. - № 4 (Педагогіка). - С. 180-182.

32. Фролова Т.В. Сучасні аспекти формування здоров'я дитячого населення / Т.В. Фролова, О.В. Охапкіна, I.P. Сіняєва // Перинатол. и педиатрия. - 2014. - № 2. C. 116-118.

33. Царук О.В. Дослідження динаміки витривалості хлопців 13-14 років, які займаються в спортивній секції 3 футболу за експериментальною програмою / О.В. Царук, В.С. Царук // Педагогіка, психологія та медико-біологічні проблеми фізичного виховання i спорту. - 2012. - № 5. - С. 124-128.

34. Anthropometry of young competitive sport rock climbers / P.B. Watts, L.M. Joubert, A.K. Lish [et al.] // British J. of Sports Medicine. - 2003. - Vol. 45. - P. 420-424.

35. Butte N.F. Evaluation of Feasibility of International Growth Standards for scool-aged children and adolescents / N.F. Butte, C. Garza, M. Onis // The J. of Nutrition. - 2007. - Vol. 137. - P. 153-157.

36. Comparison of nutritional intake in US adolescent swimmers and non-athletes / A.C. Collins, D.W. Kenneth, M. Bridget [et al.] // Scien. Res. - 2012. - Vol. 4. P. 873-880.

37. Effect of urbanization on objectively measures physical activity levels, sedentary time, and indices of adiposity in Kenyan adolescents / R.M. Ojiambo, Ch. Easton, J.A. Casajus [et al.] // Journal of Physical Activity and Health. - 2012. - Vol. 9, № 1. - P. 115-123.

38. Hayashi M. A guidebook for volleyball-related health problems using Manga and educational activities for injury prevention: Volleyball 911 / M. Hayashi, Y. Hamu, Y. Hashimoto // British Journal of Sports Medicine. 2011. - Vol. 45. - P. 548.

39. Opstoel K. Anthropometric characteristics, physical fitness and motor coordination of 9 to 11 year old children participating in a wide range of sport / K. Opstoel, J. Pion, M. Elferink-Gemser // Public Library of Science (PLOS/ ONE). - 2015. - Vol. 10 (5). - e0126282.

40. Prevalence of obesity among the scool-going children of Lahore and associated factors / A. Anwar, F. Anwar, H. Ullah Joiya [et al.] // J. Ayub. Med. Coll. Abbottabad. - 2010. - Vol. 22 (4). - P. 27-32.

\section{ОСОБЕННОСТИ СОСТОЯНИЯ ЗДОРОВЬЯ, ДВИГАТЕЛЬНОЙ АКТИВНОСТИ И ПИТАНИЯ ШКОЛЬНИКОВ-СПОРТСМЕНОВ (ОБЗОР ЛИТЕРАТУРЫ)}

\section{С.Л. Няньковский, О.Б. Пластунова}

Резюме. На основании сравнительного анализа данных литературы о состоянии здоровья и физическом развитии школьников, занимавшихся и не занимавшихся спортом, установлено, что у школьников-спортсменов преобладали болезни костно-мышечной системы, глаз, органов дихания, жалобы на боли и повреждения разных отделов опорно-двигательного аппарата, большей была частота дисгармоничного развития за счет как недостаточной, так и избыточной массы тела. Состояние здоровья юных спортсменов зависело от их возраста, стажа занятий спортом, спортивной ориентации, уровней тренировочных нагрузок, фактического питания. Указано на необходимость изучения и оценки состояния здоровья и физического развития школьников-спортсменов с учетом их двигательной 
активности, энергозатрат, фактического питания и разработки на этой основе дифференцированных по возрасту и полу норм питания юных спортсменов разной спортивной ориентации.

Ключевые слова: школьники-спортсмены, здоровье, физическое развитие, питание.

\section{FEATURES OF HEALTH STATUS, MOTION ACTIVITY AND NUTRITION OF SCHOOLCHILDREN-ATHLETES (REVIEW OF THE REFERENCES)}

\section{S.L. Nyankovskyi, O.B. Plastunova}

Abstract. Literature about physical development and health status of schoolchildren athletes and non-athletes was analyzed and compared. It was determined that among schoolchildren athletes there was a higher rate of musculoskeletal system diseases, eye diseases, respiratory system diseases, complaints about pain and also injuries of different parts of locomotor apparatus. Disharmonious physical development rate was also higher among schoolchildren athletes because of both insufficient and excessive body weight. Health status of young athletes depended on their age, sports experience, sports direction, training loads level and nutrition status. Necessity for a further investigation and evaluation of health status and physical development of schoolchildren-athletes, taking into an account their motion activity, energy consumption and actual nutrition, in order to develop basic nutrition norms differentiated by age and gender for young athletes of different sports directions, was indicated.

Key words: schoolchildren athletes, health status, physical development, nutrition.

Danylo Halytsky National Medical University (Lviv)

Рецензент - проф. Ю.М. Нечитайло
Buk. Med. Herald. - 2016. - Vol. 20, № 1 (77). - P. 206-214

Надійшла до редакції 29.12.2015 року

(с) С.Л. Няньковський, О.Б. Пластунова, 2016 